\title{
Measurement of the Cooling Efficiency of Pavement-watering as an Urban Heat Island Mitigation Technique
}

\author{
Martin A. Hendel ${ }^{* 1,2,3}$, Morgane Colombert ${ }^{2}$, Youssef Diab ${ }^{2}$, Laurent Royon ${ }^{3}$ \\ ${ }^{1}$ Paris City Hall, Water and Sanitation Department, F-75014, Paris, France \\ e-mail: martin.hendel@paris.fr \\ ${ }^{2}$ Université Paris-Est, Lab'Urba, EA 3482, EIVP, F-75019, Paris, France \\ ${ }^{3}$ Univ Paris Diderot, Sorbonne Paris Cité, MSC, UMR 7057, CNRS, F-75013, Paris, France
}

Cite as: Hendel, M. A., Colombert, M., Diab, Y., Royon, L., Measurement of the Cooling Efficiency of Pavement-watering as an Urban Heat Island Mitigation Technique, J. sustain. dev. energy water environ. syst., 3(1), pp 1-11, 2015, http://dx.doi.org/10.13044/j.sdewes.2015.03.0001

\begin{abstract}
The Paris region (Île-de-France) was amongst the hardest hit by the August 2003 heat wave, due in part to subsequent amplification of its urban heat island. This has created high heat-wave awareness in climate change adaptation studies for the city of Paris. Over the summer of 2013, pavement watering was studied experimentally in two locations as a climate change adaptation method. Pavement watering was found to lower pavement surface temperatures by several degrees for several hours after watering, while also strongly reducing its cooling rate a few hours before and after sunset. Heat flux and storage at a depth of $5 \mathrm{~cm}$ in the pavement were also found to have been significantly reduced, especially during direct sunlight exposure, but also when the pavement was in the shade. Uninterrupted watering appears necessary during direct sunlight exposure of the pavement to maximize efficiency.
\end{abstract}

\section{KEYWORDS}

Urban heat island (UHI), Climate change adaptation, Pavement watering, Pavement heat storage, Pavement surface temperature.

\section{INTRODUCTION}

The Île-de-France region was one of the worst hit in Europe during the August 2003 heat wave, due in part to subsequent amplification of its Urban Heat Island (UHI), with a two-fold increase in mortality over the first two weeks of August 2003 [1]. This event created strong heat-wave awareness in France. As a result, increases in heat-wave events are at the heart of climate adaptation work for the city of Paris under its 2007 Climate Plan.

The city of Paris funded a research project that was undertaken from 2008 to 2012 [2]. Among other aims, this work simulated different adaptation methods on the basis of a Town Energy Balance (TEB) [3] simulation of the 2003 heat wave in Paris. Among methods tested, daytime city-wide pavement-watering was investigated. Following this study, a field experiment of pavement-watering was conducted during the summer of 2012 [4]. Results showed that apparent pavement surface temperatures were reduced by up to $7{ }^{\circ} \mathrm{C}$.

Internationally, field studies have been conducted in many cities, particularly in Japan, on both traditional impervious pavements and porous or water-retaining pavements [4-8]. Yamagata et al., watering a porous water-retaining road pavement with reclaimed waste

\footnotetext{
* Corresponding author
} 
water in Tokyo, found surface temperature reductions of 3-8 ${ }^{\circ} \mathrm{C}$ [7]. Kinouchi and Kanda, using snow melting pipes to water an impervious pavement in Nagaoka City, found up to 10-30 ${ }^{\circ} \mathrm{C}$ of surface cooling [6]. They also investigate pavement heat flux and its links to net radiation. In Paris in 2012, Bouvier et al., watering the sidewalk and pavement once at night with cleaning trucks, also found $3-8{ }^{\circ} \mathrm{C}$ in surface cooling [4]. Prior work from Asaeda et al. provides information on the behaviour of pavement heat flux under normal conditions in asphalt or concrete $20-30 \mathrm{~cm}$ thick slabs [9]. They also highlight the dominant role of net radiation.

These experiments provide valuable data for the surface temperature and reduction effects of pavement-watering. However, only limited attention is given to pavement heat flux and storage effects. Furthermore, data available for such trials in Western Europe are quite scarce. Our field study was conducted over the summer of 2013 in Paris, France. We propose to investigate pavement surface temperatures and pavement heat flux and storage on July $16^{\text {th }}$ and $22^{\text {nd }}$, when additional mobile surface temperature surveys were conducted. The thermal effects of pavement-watering will be discussed in light of these data series.

\section{Materials and methods}

Conductive heat flux and surface temperatures were investigated on Rue du Louvre, near Les Halles in the $1^{\text {st }}$ and $2^{\text {nd }}$ Arrondissements. The street has an aspect ratio approximately equal to one $(\mathrm{H} / \mathrm{W}=1)$, is about $20 \mathrm{~m}$ wide and has a N-NE - S-SW orientation. It is paved with standard asphalt concrete. Weather station positions are illustrated in Figure 1.

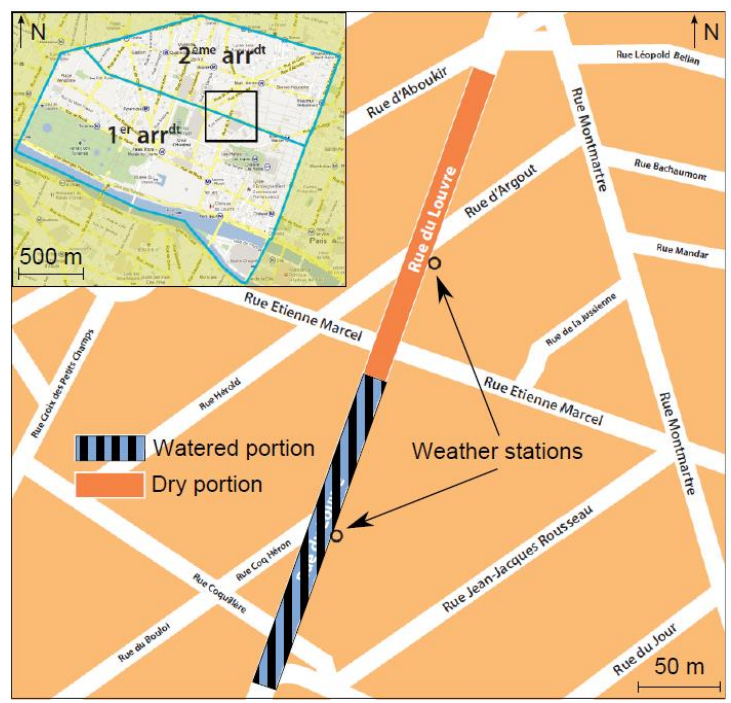

Figure 1. Map of the Rue du Louvre site

These positions were selected as their urban configuration (morphology, orientation, materials, traffic, etc.) was as similar as possible and presented very low vegetation presence. Statistical analyses were conducted using the $\mathrm{R}$ software environment, version 3.0.1, retrieved from http://www.r-project.org/ on July 30 ${ }^{\text {th }}, 2013$.

\section{Watering method}

Watering was started if certain weather conditions, based on Météo-France's three-day forecast, were met. These are summarized in Table 1. Heat-wave warnings are issued if $\mathrm{BMI}_{\min }$ and $\mathrm{BMI}_{\max }$ exceed $21^{\circ} \mathrm{C}$ and $31^{\circ} \mathrm{C}$, respectively. 
Table 1. Weather conditions for pavement-watering

\begin{tabular}{cc}
\hline Parameter & Threshold \\
\hline Mean three-day minimum air temperature & $\geq 25{ }^{\circ} \mathrm{C}$ \\
$\left(\mathrm{BMI}_{\min }\right)$ & $\geq 16^{\circ} \mathrm{C}$ \\
Mean three-day maximum air temperature & $\leq 10 \mathrm{~km} / \mathrm{h}$ \\
$\left(\mathrm{BMI}_{\max }\right)$ & Wind speed \\
Sky conditions & Sunny (less than 2 oktas cloud \\
\end{tabular}

Cleaning trucks were used to sprinkle approximately $11 / \mathrm{m}^{2}$ (equivalent to $1 \mathrm{~mm}$ ) every hour from 6:30 AM to 11:30 AM and every 30 minutes from 2 PM until 6:30 PM on the sidewalk and pavement. A photograph of pavement-watering is shown in Figure 2.

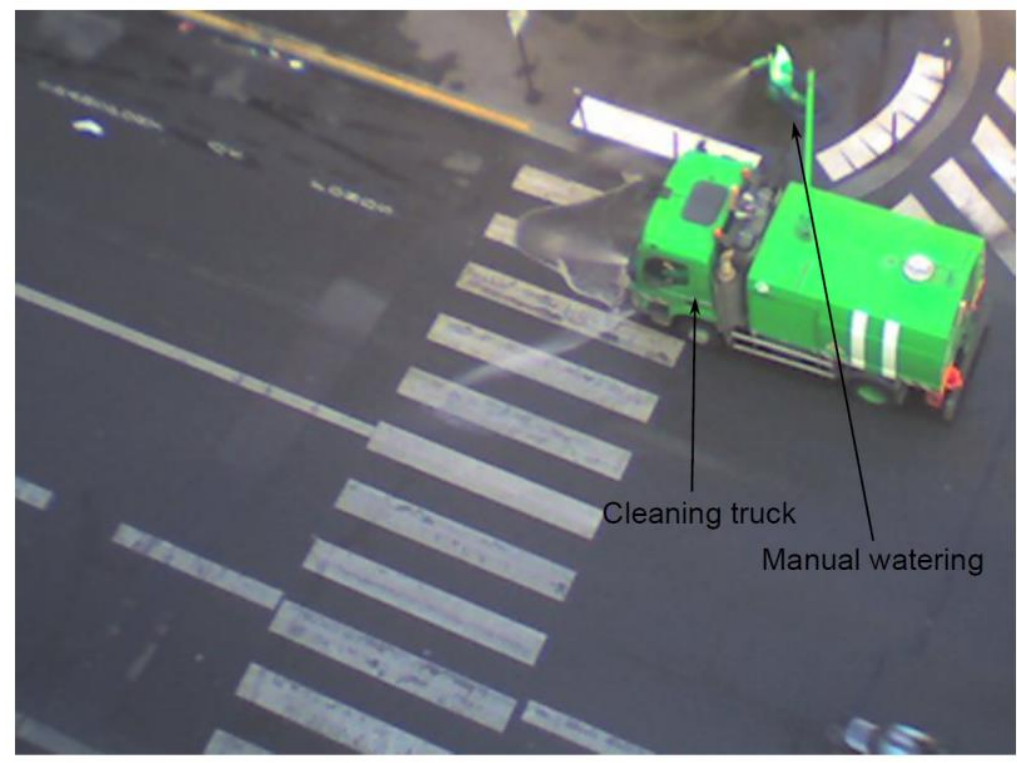

Figure 2. Watering of the pavement and sidewalk on Rue du Louvre

Each watering cycle implies two passes by the cleaning truck. During each pass, the driver waters the two traffic lanes going in his direction, while an operator waters the sidewalk with a high pressure spray. The watering cycle start and end times were reported by the driver. The precision of reporting is estimated to be no better than 5 minutes. The capacity of the cleaning truck is $4 \mathrm{~m}^{3}$, i.e. just $10 \%$ more than required for the target area. The cleaning truck therefore refilled between each cycle. The average watering cycle, including watering and refilling, lasted about 20 minutes.

Water used for this experiment was supplied by the city's 1,600 km non-potable water network, principally sourced from the Ourcq Canal. This water network is currently regarded as having high sustainability potential for urban uses that do not require potable water.

It should be noted that applying this watering method to Paris' 2,550 ha of roads and sidewalks would require more than $300,000 \mathrm{~m}^{3} /$ day and over 6,000 cleaning trucks. Although this method is clearly unfeasible, it is the simplest way of experimentally watering the road surface while saturating its water-retaining capacity and controlling water consumption. 


\section{Pavement sensor}

The pavement at each site was equipped with a thermo-flowmeter at a depth of $5 \mathrm{~cm}$, in the centre of the adjoining bus lane. Figure 3 illustrates a top view of sensor installation.

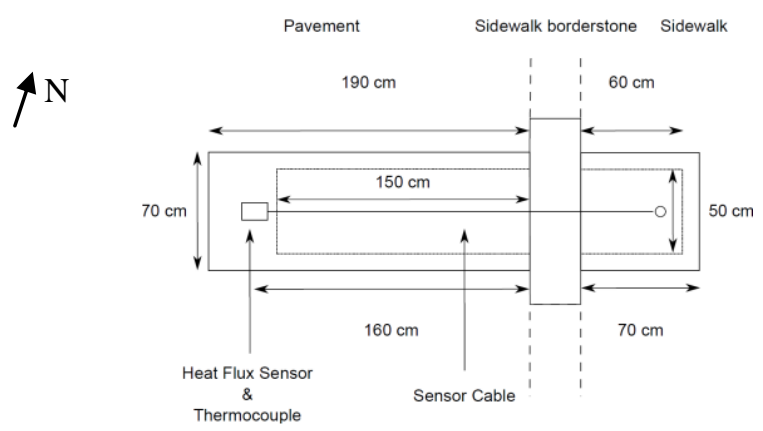

Figure 3. Top view of pavement sensor

In a masked environment such as ours, heat flux sensor positioning determines the exact aspect of the heat flux curve as it defines the beginning and end of pavement insolation, the main contributing factor to pavement heat flux. All else being equal, different positions are therefore not expected to significantly affect our analysis. This should also hold true for streets with similar orientation or aspect ratio. However, differences in paving materials will significantly affect pavement heat flux due to changes in albedo and emissivity. We therefore consider our analysis to be generalizable to all grossly $\mathrm{N}-\mathrm{S}$ oriented streets with standard asphalt pavement and an aspect ratio of one.

\section{Heat transfer model}

Figure 4, based on Kinouchi and Kanda [6], summarizes the heat transfers involved at the pavement surface. Downward solar irradiance is written as $S ; L_{\text {down }}$ is downward longwave radiation; $L_{\text {up }}$ is upward longwave radiation; $S_{\text {reflected }}$ is reflected shortwave radiation; $H$ is the upward sensible heat flux; $V$ is the downward pavement heat flux at the surface; $\Delta Q$ is the heat storage flux by the first $5 \mathrm{~cm}$ layer of pavement; $l E$ is the latent heat flux, with $l$ the latent heat of vaporization and $E$ the evaporation rate. Our flowmeter measures the downward conductive heat flow $5 \mathrm{~cm}$ deep, written as $G$.

Under normal heat-wave conditions, the surface is dry and no latent heat flux is present. The role of pavement-watering is to add a latent heat flux $l E$ as well as an advective heat flux, not shown in Figure 4. The advective flux is created as the sprinkled water heats up from its distribution temperature to the surface temperature of the pavement under wet conditions before evaporating. These two fluxes are expected to cause pavement surface cooling and cascade into micro-climatic effects.

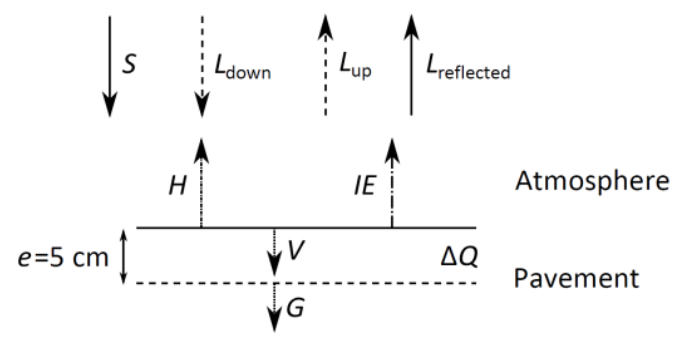

Figure 4. Pavement surface heat budget 


\section{Weather station design}

The pavement temperature and heat flux sensor was connected to a weather station used for microclimatic measurements. These included air temperature, relative humidity, black globe temperature, wind (velocity and direction), presence of rain and solar irradiance as indicated on Figure 5. Instruments within pedestrian reach were protected behind a cage.

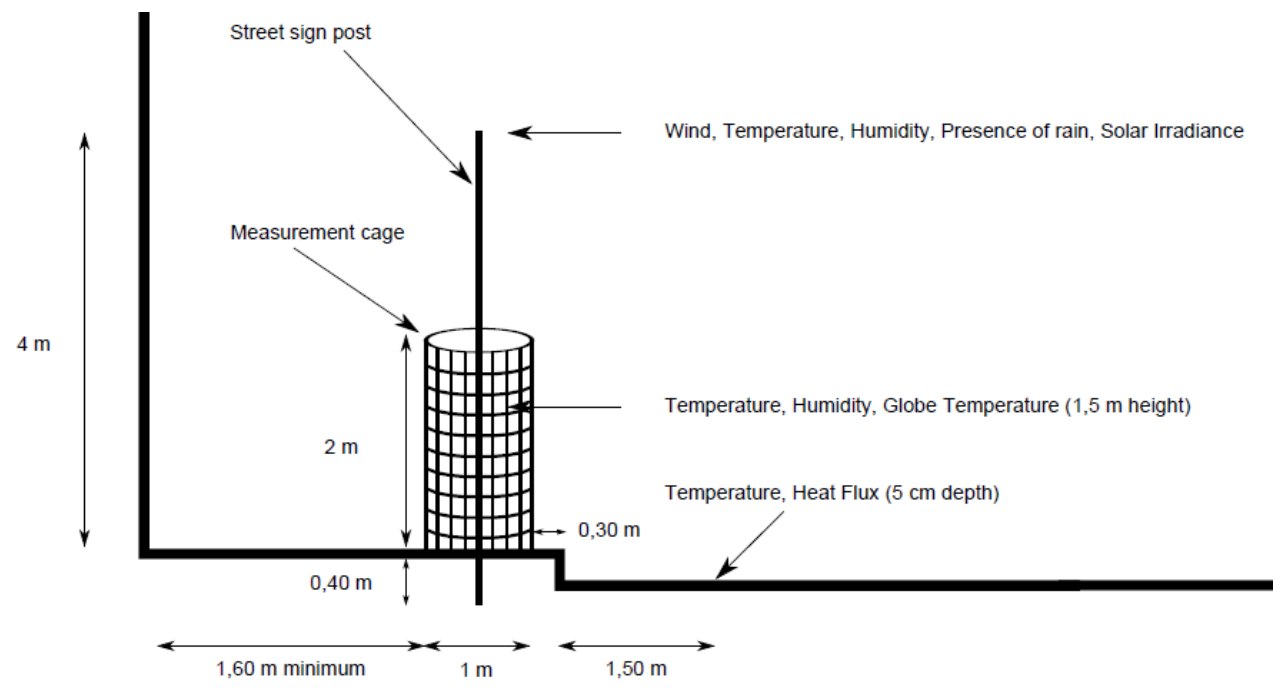

Figure 5. Design of urban weather stations installed Rue du Louvre

Table 2 summarizes the instruments and data used for this analysis. Black globe temperature, wind speed and air temperature were used to calculate mean radiant temperature, as described by ASHRAE [10].

Table 2. Instrument type, measurement height and accuracy

\begin{tabular}{|c|c|c|c|c|}
\hline Parameter & Instrument & Height & Accuracy & Parameter \\
\hline Solar irradiance & $\begin{array}{c}\text { Second class } \\
\text { pyranometer ISO } 9060\end{array}$ & $4 \mathrm{~m}$ & $2 \%$ daily & Solar irradiance \\
\hline $\begin{array}{l}\text { Pavement heat } \\
\text { flux }\end{array}$ & Taylor-made flowmeter & $-5 \mathrm{~cm}$ & - & $\begin{array}{l}\text { Pavement heat } \\
\text { flux }\end{array}$ \\
\hline Relative humidity & Capacitive hygrometer & $1.5 \mathrm{~m}$ & $1.5 \%$ & Relative humidity \\
\hline Air temperature & Pt100 1/3 DIN B & $1.5 \mathrm{~m}$ & $0.1^{\circ} \mathrm{C}$ & Air temperature \\
\hline $\begin{array}{l}\text { Black globe } \\
\text { temperature }\end{array}$ & $\begin{array}{c}\text { Pt100 1/2 DIN A } \\
\text { ISO } 7726\end{array}$ & $1.5 \mathrm{~m}$ & $0.15^{\circ} \mathrm{C}$ & $\begin{array}{l}\text { Black globe } \\
\text { temperature }\end{array}$ \\
\hline Wind speed & $\begin{array}{l}\text { 2D ultrasonic } \\
\text { anemometer }\end{array}$ & $4 \mathrm{~m}$ & $2 \%$ & Wind speed \\
\hline
\end{tabular}

\section{Thermal imaging}

A Flir B400 thermal camera was positioned on the roof terrace of 46, Rue du Louvre. The camera recorded false-color IR thermal and visible images simultaneously every hour on non-watered days and every 10 or 15 minutes on watered days. Additional mobile thermal images were taken on site on the evenings of the $16^{\text {th }}$ and $22^{\text {nd }}$ of July with a Fluke TiR32 camera lent by the Parisian Urban Planning Agency (APUR).

These images were used to estimate pavement surface temperature. Apparent (measured) surface temperatures were corrected as presented in Table 3. 
Table 3. Parameters used to correct apparent surface temperature

Parameter

Flir B400

Fluke TiR32

(spectral range: $7.5-13 \mu \mathrm{m}$ )

(spectral range: $7.5-14 \mu \mathrm{m}$ )

\begin{tabular}{|c|c|c|}
\hline Pavement emissivity & 0.97 & 0.97 \\
\hline $\begin{array}{l}\text { Reflected } \\
\text { temperature }\end{array}$ & \multicolumn{2}{|c|}{$\begin{array}{c}\text { Mean Radiant Temperature (MRT) as measured by weather } \\
\text { station }\end{array}$} \\
\hline Distance to target & $20 \mathrm{~m}$ & Correction unavailable \\
\hline Relative humidity & $\begin{array}{c}\text { As measured at } 1.5 \mathrm{~m} \text { by } \\
\text { weather station }\end{array}$ & Correction unavailable \\
\hline Air temperature & $\begin{array}{c}\text { As measured at } 1.5 \mathrm{~m} \text { by } \\
\text { weather station }\end{array}$ & Correction unavailable \\
\hline
\end{tabular}

The emissivity of pavement surfaces was measured in the field using an adhesive of known emissivity.

\section{Results and discussion}

Mobile IR thermal photography surveys were conducted with the Fluke TiR32 infrared camera on the $16^{\text {th }}$ and $22^{\text {nd }}$ of July, 2013, from 6:30 PM until 11 PM. Heat flux and storage will also be discussed for these days and compared to those of two control days: July $14^{\text {th }}$ and $20^{\text {th }}$, respectively.

\section{Infrared thermal photography surveys}

Two equivalent zones of pavement, one watered and one control, were studied. Collected data is presented in Figure 6 a, b, as well as surface temperature measurements of an equivalent watered pavement zone made by the Flir camera on the roof-terrace. Fitted regression models for the Fluke data are plotted as well.

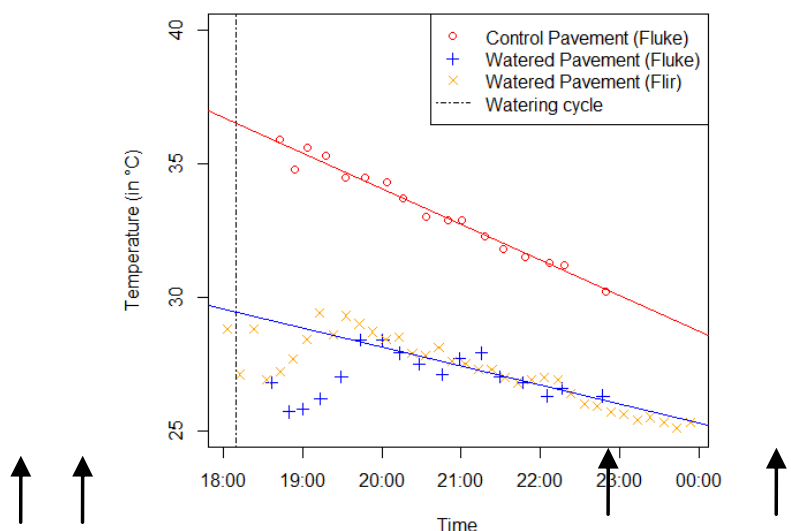

(a)

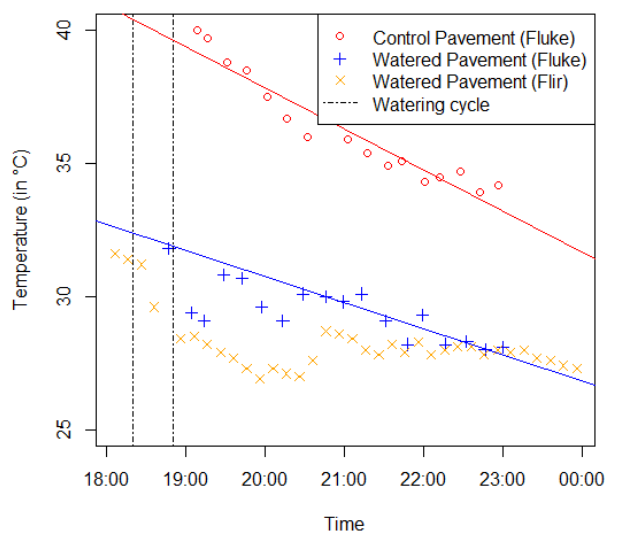

(b)

Figure 6. Evolution of corrected pavement surface temperatures: a) 16/07; b) 22/07 Arrows indicate sudden increases or decreases in the Flir data series

The last watering cycle was completed at 6:10 PM on July $16^{\text {th }}$, while it ended at 6:50 PM on July $22^{\text {nd }}$. These events are marked with a dash-dotted vertical line. All Fluke thermal images were of shaded areas, while this was not the case for plotted Flir data prior to 6:30 PM. 
On both days, Flir measurements are subject to sudden declines and increases between 6 PM and 9 PM. These events are marked in Figure 6 with arrows on the $\mathrm{x}$-axis. The magnitude of these events is about $3{ }^{\circ} \mathrm{C}$ on July $16^{\text {th }}$ and $2{ }^{\circ} \mathrm{C}$ on July $22^{\text {nd }}$. These coincide with the high variability seen in the Fluke data before $7: 30$ PM on July $16^{\text {th }}$ and before 8:30 PM on July $22^{\text {nd }}$.

These two shifts are respectively caused by pavement shading and surface drying, possibly caused by shortcomings in the applied correction of apparent temperatures. For these reasons, the regressions of the Fluke watered pavement series were only conducted on data collected after pavement drying, i.e. after 7:30 PM on July $16^{\text {th }}$ and after 8:30 PM on July $22^{\text {nd }}$. The linear model fit was conducted on the whole of the control series.

Table 4 summarizes relevant regression parameters for the control and watered pavements. Given the degrees of freedom, Student tests indicate that the correlations found are at least $99.9 \%$ significant on July $16^{\text {th }}$ and July $22^{\text {nd }}$ for both watered and control pavements.

It can therefore be said with high confidence that, over the survey period, the surface temperatures in the control area cool nearly twice as fast as those in the watered area, with a difference of about $7.5^{\circ} \mathrm{C}$ at $7: 30 \mathrm{PM}$ on July $16^{\text {th }}$. For July $22^{\text {nd }}$, which was significantly warmer than July $16^{\text {th }}$, the control cools nearly $60 \%$ faster than the watered pavement, with a difference of about $6^{\circ} \mathrm{C}$ at 8:30 PM.

The lower cooling rate of the pavement surface translates lower heat release by the pavement in the hours following pavement drying after watering compared to control conditions. This also indicates lower heat storage by the road materials.

Table 4. Regression parameters

\begin{tabular}{ccccc}
\hline \multirow{2}{*}{ Parameter } & \multicolumn{2}{c}{ July $16^{\text {th }}, 2013$} & \multicolumn{2}{c}{ July 22 $2^{\text {nd }}, 2013$} \\
\cline { 2 - 5 } & Control & Watered & Control & Watered \\
& pavement & pavement & pavement & pavement \\
\hline Slope & $-1.33 \mathrm{~K} / \mathrm{h}$ & $-0.71 \mathrm{~K} / \mathrm{h}$ & $-1.54 \mathrm{~K} / \mathrm{h}$ & $-0.98 \mathrm{~K} / \mathrm{h}$ \\
$R$-squared & 0.9759 & 0.8262 & 0.6052 & 0.7844 \\
$t$ coefficient & -24.64 & -6.896 & -12.50 & -5.395 \\
Degrees of Freedom & 15 & 10 & 14 & 8 \\
\hline
\end{tabular}

\section{Heat flux}

Due to difficulties encountered with the control pavement sensor, watered data from July $16^{\text {th }}$ and $22^{\text {nd }}$ will be compared respectively to unwatered data from July $14^{\text {th }}$ and $20^{\text {th }}$ measured at the experimental station. On July $16^{\text {th }}$, the Météo-France forecast indicated daily minimum and maximum temperatures of $20^{\circ} \mathrm{C}$ and $29^{\circ} \mathrm{C}$. On July $22^{\text {nd }}$, these values were $23^{\circ} \mathrm{C}$ and $35^{\circ} \mathrm{C}$, respectively.

Heat flux is highly dependent on solar irradiance. Solar irradiance was $13 \%$ lower on July $16^{\text {th }}$ than on July $14^{\text {th }}$, due to intermittent cloud cover throughout the day. The $4 \%$ difference between solar irradiance on July $20^{\text {th }}$ and $22^{\text {nd }}$ is considered negligible. Sunrise occurred at 5:58 AM and $6 \mathrm{AM}$ for July $14^{\text {th }}$ and $16^{\text {th }}$, while sunset was at 9:52 PM and 9:50 PM, respectively. On July $20^{\text {th }}$ and $22^{\text {nd }}$, these occurred at 6:04 AM, 6:07 AM, 9:46 PM and 9:44 PM, respectively. Solar irradiance was highest between 1:30 PM and 3 PM.

Figure $7 \mathrm{a}, \mathrm{b}, \mathrm{c}$ and d illustrate measured heat flux on July $16^{\text {th }}, 22^{\text {nd }}, 14^{\text {th }}$ and $20^{\text {th }}$, respectively. Dot-dash vertical lines indicate watering. Control day heat flux ranges between $-50 \mathrm{~W} / \mathrm{m}^{2}$ and $200 \mathrm{~W} / \mathrm{m}^{2}$ and follows a skewed-bell-shaped curve. On July $20^{\text {th }}$, a parked tour bus is responsible for the 30 minute heat flux gap at 2:15 PM. These values are consistent with findings by Asaeda et al. and Kinouchi and Kanda [6, 9]. 
On watered days however, this shape is very significantly altered. This is especially the case in the afternoon during pavement insolation. In addition, watering cycles coincide well with local heat flux maxima, although this isn't always the case because of intermittent cloud cover.

On July $16^{\text {th }}$, maximum heat flux is reached when afternoon watering commences, with an approximate value of $110 \mathrm{~W} / \mathrm{m}^{2}$. On July $22^{\text {nd }}$; the maximum value of $134 \mathrm{~W} / \mathrm{m}^{2}$ is also reached a few minutes before afternoon watering begins.

The delay in watering on July $22^{\text {nd }}$ compared to July $16^{\text {th }}$, due to a delay in the start of pavement-watering, is part of the reason why the observed heat flux maximum is higher, although a passing cloud caused the July $22^{\text {nd }}$ peak to be reached a few minutes before watering. Had there been no interruption of solar irradiance, it is likely that the maximum would have been higher.

For these two days, heat flux maxima are reached during direct sun exposure, just after long interruptions of watering which allowed the surface to dry. The insolation period is that when pavement surface temperatures are expected to be highest. Therefore, it is also the period when advective and evaporative cooling should be highest. These periods, especially that just before the beginning of pavement insolation, therefore appear to be those with the greatest potential to increase the cooling effect.

This suggests that if cities are to carry out large-scale pavement watering, it is crucial to maintain active watering throughout the full duration of the insolation period in order to keep heat flux at a minimum, especially at midday when solar irradiance is highest. In order to avoid heat flux maxima from occuring during pavement watering, a higher watering frequency may be necessary.

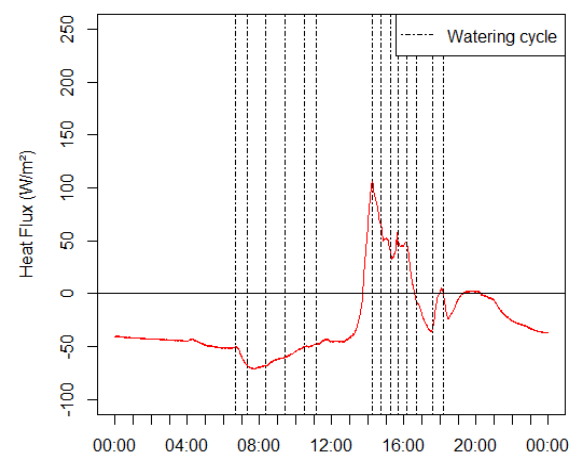

(a)

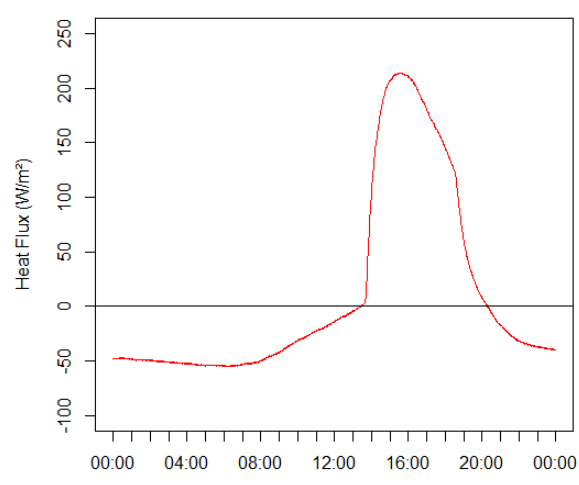

(c)

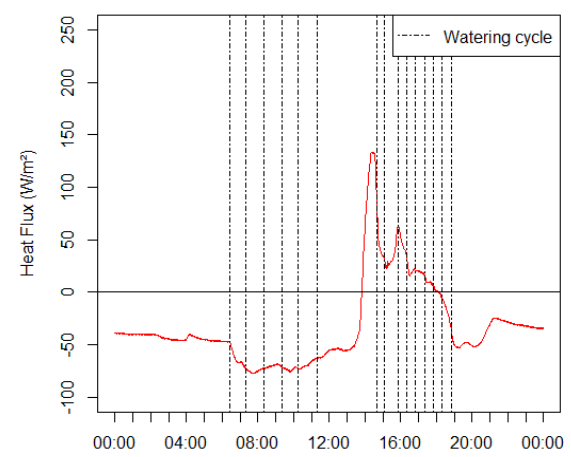

(b)

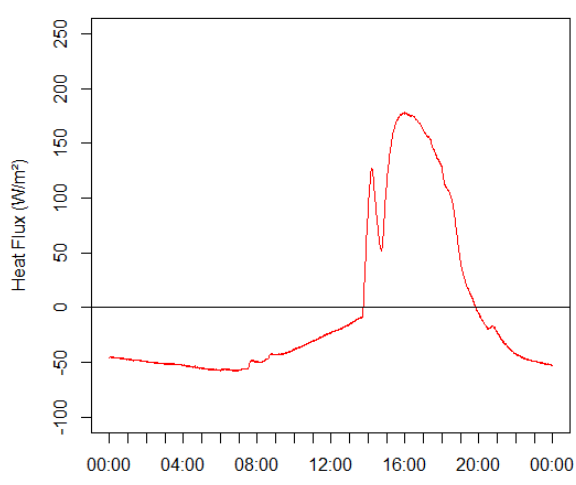

(d)

Figure 7. Heat flux measured at $5 \mathrm{~cm}$ depth by the 46, Rue du Louvre weather station a) $16 / 07$; b) $22 / 07$; c) $14 / 07$; d) $20 / 07$ 


\section{Heat storage}

A day-by-day analysis of heat storage will now be conducted. Heat storage was obtained by integration of the measured heat flux by the trapezoidal rule. The analysis will also take a closer look at different periods of the day, defined as follows: morning, the period before pavement insolation, which is divided into two parts: before watering begins, and after watering begins; afternoon is the period of direct sun exposure; evening is the period after direct sun exposure has ended.

Table 5 and Table 6 summarize heat storage on July $14^{\text {th }}$ and $16^{\text {th }}$, and July $20^{\text {th }}$ and $22^{\text {nd }}$, respectively. The difference between the sum of the different periods and the indicated total is due to double counting at interval extrema.

For both periods, daily heat storage is significantly reduced: from $0.90 \mathrm{MJ} / \mathrm{m}^{2}$ on July $14^{\text {th }}$ to $-2.33 \mathrm{MJ} / \mathrm{m}^{2}$ on July $16^{\text {th }}$ and from $-0.19 \mathrm{MJ} / \mathrm{m}^{2}$ on July $20^{\text {th }}$ to $-2.81 \mathrm{MJ} / \mathrm{m}^{2}$ on July $22^{\text {nd }}$. The pavement was therefore a net releaser of heat on watered days.

Judging by the details in Table 5 and Table 6, it appears that pavement-watering is most effective at mitigating heat storage during the watering phase, when the latent and advective heat fluxes are present. Furthermore, the effect is maximised during direct insolation of the pavement, when advective and evaporative are expected to be highest.

Table 5. Heat storage (in MJ/m²) on July $14^{\text {th }}$ and $16^{\text {th }}, 2013$

\begin{tabular}{|c|c|c|c|c|c|}
\hline \multirow[b]{2}{*}{ Date } & \multicolumn{2}{|c|}{ Morning } & \multirow[b]{2}{*}{ Afternoon } & \multirow[b]{2}{*}{ Evening } & \multirow[b]{2}{*}{ Total } \\
\hline & $\begin{array}{c}\text { Before } \\
\text { watering }\end{array}$ & $\begin{array}{c}\text { During } \\
\text { watering }\end{array}$ & & & \\
\hline July $14^{\text {th }}, 2013$ & -1.25 & -0.75 & 3.15 & -0.28 & 0.90 \\
\hline July $16^{\text {th }}, 2013$ & -1.09 & -1.34 & 0.37 & -0.31 & -2.33 \\
\hline $\begin{array}{c}\text { Difference } \\
\text { (Watered-control) }\end{array}$ & $\begin{array}{l}+0.16 \\
+13 \%\end{array}$ & $\begin{array}{l}-0.59 \\
-79 \%\end{array}$ & $\begin{array}{l}-2.78 \\
-88 \%\end{array}$ & $\begin{array}{l}-0.03 \\
-10 \%\end{array}$ & -3.23 \\
\hline
\end{tabular}

Table 6. Heat storage (in $\mathrm{MJ} / \mathrm{m}^{2}$ ) on July $20^{\text {th }}$ and $22^{\text {nd }}, 2013$

\begin{tabular}{|c|c|c|c|c|c|}
\hline \multirow[b]{2}{*}{ Date } & \multicolumn{2}{|c|}{ Morning } & \multirow[b]{2}{*}{ Afternoon } & \multirow[b]{2}{*}{ Evening } & \multirow[b]{2}{*}{ Total } \\
\hline & $\begin{array}{c}\text { Before } \\
\text { watering }\end{array}$ & $\begin{array}{c}\text { During } \\
\text { watering }\end{array}$ & & & \\
\hline July $20^{\text {th }}, 2013$ & -1.20 & -0.90 & 2.36 & -0.49 & -0.19 \\
\hline July $22^{\text {nd }}, 2013$ & -1.01 & -1.70 & 0.52 & -0.67 & -2.81 \\
\hline $\begin{array}{c}\text { Difference } \\
\text { (Watered-control) }\end{array}$ & $\begin{array}{l}+0.19 \\
+16 \%\end{array}$ & $\begin{array}{l}-0.80 \\
-89 \%\end{array}$ & $\begin{array}{l}-1.84 \\
-78 \%\end{array}$ & $\begin{array}{l}-0.18 \\
-27 \%\end{array}$ & -2.62 \\
\hline
\end{tabular}

However, because of intermittent cloud cover on July $16^{\text {th }}$, the observed effect is probably overestimated. Inversely, due to the heat flux gap caused by a parked tour bus on July $20^{\text {th }}$, the effect observed on July $22^{\text {nd }}$ is probably underestimated.

Overall, if local shading effects are taken into account, it appears that pavement watering is an effective means of reducing heat storage by the pavement below $5 \mathrm{~cm}$. A closer look at the period after pavement drying in the evening would give a better idea of the effects of pavement-watering on nocturnal heat release by road materials.

\section{CONCLUSION}

In this paper the effect of pavement watering on surface temperatures and on heat flux and storage $5 \mathrm{~cm}$ below the pavement surface was discussed. These aspects were 
investigated for a street with a N-NE-S-SW orientation and an aspect ratio of one. The road materials were standard, impervious asphalt pavement, a commonly found material in Parisian streets.

Watering was shown to be effective at lowering pavement surface temperatures by several degrees for several hours and significantly reducing the pavement surface cooling rate up to $50 \%$ after watering.

Downward pavement heat flux was also found to be significantly reduced by watering. The cooling effect was at its highest during pavement insolation, when advection and evaporation are expected to be greatest.

Finally, heat storage was shown to be significantly lowered, resulting in a negative storage balance for watered days. The reduction in heat storage was highest as watering was taking place, but smaller residual effects were noted after watering had ended as well. As found for pavement heat flux, the greatest effect was achieved during direct insolation of the pavement, although it was not possible to precisely quantify this effect.

From these analyses, it was determined that the greatest potential for improvement of the cooling effect lies in maintaining pavement watering throughout the insolation period, particularly at midday when solar irradiance is highest.

These findings are expected to be generalizable to other streets with similar orientation, aspect ratio and paving materials. However, other configurations and materials should be explored before a city-wide strategy can begin to be elaborated. Further investigation into the micro-climatic effects of pavement watering is also required to ascertain the full benefits of the method. Further research into the optimization of the watering method will help minimize water consumption while maximizing its cooling effects. This will help decision-makers decide whether or not this method is viable at a larger scale.

\section{ACKNOWLEDGEMENTS}

The authors would like to thank APUR and Orange for lending their infrared camera and the roof-terrace of their building located at 46, Rue du Louvre at no cost for the purpose of this experiment. They also acknowledge the support of Météo-France and APUR as well as the Green Spaces and Environment, Roads and Traffic and the Waste and Water Divisions of the City of Paris during the preparation phase of this experiment.

Funding for this experiment was provided for by the Water and Sanitation Department of the City of Paris.

\section{NOMENCLATURE}

\begin{tabular}{|c|c|}
\hline \multicolumn{2}{|c|}{ bbreviations } \\
\hline APUR & Paris Urban Planning Agency \\
\hline $\mathrm{BMI}_{\max }$ & Maximum biometeorological index, 3 day mean of daily high temperature \\
\hline $\mathrm{BMI}_{\min }$ & Minimum biometeorological index, 3 day mean of daily low temperature \\
\hline G & Pavement heat flux at $5 \mathrm{~cm}$ depth \\
\hline $\mathrm{H}$ & Surface-to-atmosphere sensible heat flux \\
\hline IR & Infrared Radiation \\
\hline $\mathrm{L}_{\mathrm{up}}$ & Upward longwave radiation \\
\hline $\mathrm{L}_{\text {down }}$ & Downward longwave radiation \\
\hline MRT & Mean Radiant Temperature \\
\hline $\mathrm{S}$ & Solar irradiance \\
\hline$S_{\text {reflected }}$ & Reflected visible radiation \\
\hline TEB & Town Energy Balance \\
\hline
\end{tabular}


UHI Urban Heat Island

V Pavement heat flux at surface

WBGT Wet-Bulb-Globe-Temperature

\section{REFERENCES}

1. Robine, J. M., Cheung, S. L. K., Le Roy, S., Van Oyen, H., Griffiths, C., Michel, J. P. and Herrmann, F. R., Death Toll Exceeded 70,000 in Europe during the Summer of 2003., C. R. Biol., Vol. 331, No. 2, pp 171-178, 2008, http://dx.doi.org/10.1016/j.crvi.2007.12.001

2. Météo-France and CSTB, EPICEA - Rapport final, 2012.

3. Masson, V., A Physically-based Scheme for the Urban Energy Budget in Atmospheric Models, Boundary-Layer Meteorol., Vol. 94, No. 3, pp 357-397, 2000, http://dx.doi.org/10.1023/A:1002463829265

4. Bouvier, M., Brunner, A. and Aimé, F., Nighttime Watering Streets and Induced Effects on the Surrounding refreshment in Case of Hot Weather, The City of Paris Experimentations, Tech. Sci. Méthodes, No. 12, pp 43-55 (In French), 2013, http://dx.doi.org/10.1051/tsm/201312043

5. Kinouchi, T., and Kanda, M., An Observation on the Climatic Effect of Watering on Paved Roads, J. Hydrosci. Hydraul. Eng., Vol. 15, No. 1, pp 55-64, 1997.

6. Kinouchi, T. and Kanda, M., Cooling Effect of Watering on Paved Road and Retention in Porous Pavement, in Second Symposium on Urban Environment, pp 255-258, 1998.

7. Yamagata, H., Nasu, M., Yoshizawa, M., Miyamoto, A. and Minamiyama, M., Heat Island Mitigation using Water Retentive Pavement sprinkled with reclaimed Wastewater, Water Sci. Technol. a J. Int. Assoc. Water Pollut. Res., Vol. 57, No. 5, pp 763-771, 2008, http://dx.doi.org/10.2166/wst.2008.187

8. Takahashi, R. Asakura, A., Koike, K., Himeno, S. and Fujita, S., Using Snow Melting Pipes to verify the Water Sprinkling's Effect over a Wide Area, in NOVATECH 2010, pp 10, 2010.

9. Asaeda, T., Ca, V. T. and Wake, A., Heat Storage of Pavement and its Effect on the Lower Atmosphere, Atmos. Environ., Vol. 30, No. 3, pp 413-427, 1996, http://dx.doi.org/10.1016/1352-2310(94)00140-5

10. ASHRAE, ASHRAE Fundamentals Handbook 2001, SI Edition, American Society of Heating, Refrigerating, and Air-Conditioning Engineers, 2001. 